\title{
GREEN DELIVERY V OBLASTI POSLEDNEJ MÍLE V POŠTOVÝCH PODNIKOCH NA SLOVENSKU
}

\section{Iveta Kremeňová1, Dominika Koncová ${ }^{2}$}

\begin{abstract}
The paper aims to show ecological road transport vehicles used by postal operators in Slovakia. Firstly, there is explained theoretical background of the problem. Secondly, there is explained aim of the paper. Next, we executed analysis of Slovak postal companies' webpages, where we searched for information about their logistic fleet. In conclusion, there are stated results as well as possible reason, why only a few of them use ecological vehicles.
\end{abstract}

Keywords: last mile, postal operator, green delivery

\section{Úvod}

Mnohé podniky, ktoré v nejakej svojej činnosti zabezpečujú logistiku musia v súčasnosti dbat' ako na ceny pohonných hmôt, tak na legislatívne požiadavky spojenej sa transportom. V dnešnej dobe sa do popredia dostávajú prepravné prostriedky, ktoré sú bud' hybridnej povahy alebo majú pohon na alternatívne zdroje energie. V závislosti od formy dopravy je možné využit' aj rôzne typy pohonných látok.

V poštových podnikoch sa postupne začínajú zavádzat' elektromobily v rámci cestnej dopravy, čím sa tieto podniky snažia znížit' uhlíkovú stopu na minimum. Podobne postupujú aj zasielatel'ské a logistické spoločnosti, čím si u niektorých zákazníkov získavajú dobrú reputáciu. Avšak podl’a niektorých zákazníkov je dopad na životné prostredie nepodstatný a zaujíma ich obvykle okamžitý zisk a minimalizácia nákladov na transport zásielky.

V článku bude rozobratý pojmový aparát voblasti hybridných dopravných prostriedkov v nadväznosti na poštové a logistické podniky. Následne bude vykonaná analýza poštových podnikov, pôsobiacich v Slovenskej republike, v oblasti využitia alebo zavádzania ekologických typov vozidiel a následne bude vyhodnotené. V závere budú spísané zistenia vykonanej analýzy.

\section{Teoretické pozadie riešenej problematiky}

Ked' sa uvažuje nad ekologickejšou formou dopravy, je nutné uvažovat' bud' o druhu dopravy alebo v prípade konkrétneho typu dopravy o využití ekologických dopravných prostriedkov. Ekologickými vozidlami môžu byt' elektromobily, či hybridné vozidlá, prípadne dopravné prostriedky, ktoré neprodukujú emisie s obsahom oxidu uhličitého (d’alej ako $\mathrm{CO}_{2}$ ). V rámci dopravy je možné sa zamýšl'at' nad dopravnými prostriedkami pre vodnú, cestnú leteckú alebo železničnú dopravu. Obvykle však využitie ekologickejšej formy energie v oblasti dopravy môže predstavovat' nárast doby transportu zásielky, najmä, ak sa jedná o leteckú a vodnú dopravu. V oblasti železničnej dopravy môže byt' pohon riešený bud'

\footnotetext{
${ }^{1}$ doc. Ing. Iveta Kremeňová, PhD., Žilinská univerzita v Žiline, Fakulta prevádzky a ekonomiky dopravy a spojov, Katedra spojov, Univerzitná 8215/1,01026 Žilina, Slovensko, e-mail: iveta.kremenova@fpedas.uniza.sk ${ }^{2}$ Ing. Dominika Koncová, Žilinská univerzita v Žiline, Fakulta prevádzky a ekonomiky dopravy a spojov, Katedra spojov, Univerzitná 8215/1, 01026 Žilina, Slovensko, e-mail: dominika.koncova@stud.uniza.sk
} 
prostredníctvom elektrickej energie, hybridne (kombinácia elektrickej energie a spal'ovacieho motora) alebo napr. prostredníctvom magnetickej levitácie (napr. MagLev). Ciel'om tohto článku však bude identifikovat' cestné dopravné prostriedky využívanej v cestnej doprave. Tu je možné selektovat' ekologickejšie dopravné prostriedky na hybridy a elektromobily. [1], [2]

Pod pojmom hybridný pohon sa rozumie pohon, ktorý je zabezpečovaný minimálne dvomi rozdielnymi typmi pohonu. Obvykle takýto pohon je ekologickejším variantom v porovnaní so spal'ovacími motormi na benzín alebo dieselových motorov na naftu. Čo sa týka ekonomike, samotný pohon môže byt' ekonomickejší avšak obstarávacia cena vozidla býva obvykle vyššia v porovnaní s ostatnými automobilmi. Hybridné automobily môžu pozostávat' z kombinácie spal'ovacieho motora a batérie (napr. plug-in hybrid, full hybrid, mild hybrid, micro hybrid, sériový hybrid, paralelný hybrid, through the road hybrid, sériovoparalelný hybrid). Premena, či už dieselového alebo spal'ovacieho motora, na motor poháňaný LPG (kvapalný ropný plyn) alebo v prevedení CNG (stlačený prírodný plyn - konkrétne metán) je d’alšou z možností, pomerne ekologického riešenia elektromobilu alebo nákladného automobilu. Ďalším riešením je aj využitie vodíkového pohonu, toto je však obvykle $\mathrm{v}$ jednotlivých štátoch len vo forme skúmania, prípadne v počiatkoch používania. Rovnako, nie všetky automobilky sa stotožňujú s využitím vodíku ako pohonnej látky. Ekologické doručenie je možné označovat' aj pojmom zelené doručovanie. Príkladom podniku poskytujúceho univerzálnu poštovú službu a ktorý disponuje niektorým z typov ekologických vozidiel je napr. Česká pošta, s.p., ktorá disponuje 421 vozidlami na pohon CNG a 4 elektromobilmi. [3], [4], [5], [6], [7], [8], [9]

Okrem ekologického doručovania dopravnými prostriedkami akými sú automobily a nákladné automobily je v rámci cestnej premávky možné považovat' za ekologické aj doručovanie poštovým doručovatel'om (napr. Slovenská pošta) alebo doručovanie pomocou bicyklov (napr. Švihaj šuhaj). [10], [11]

\section{Ciel' a metodológia}

Ciel’om článku je zistit’ aktuálny stav využívania ekologických vozidiel pri doručovaní zásielok v poslednej míli $\mathrm{v}$ rámci poštových podnikov pôsobiacich na Slovensku. Excerpovaním údajov z výročných správ, webových stránok ako aj noviniek (dostupných na webovom sídle firmy) v rámci poštových operátorov pôsobiacich na území Slovenskej republiky bola vykonaná sekundárna analýza. Na základe nej bola následne analyzovaná situácia a vyvodené výsledky pomocou dedukcie.

\section{Výsledky}

K dátumu 8.10.2021 na základe Registra poštových podnikov (d’alej ako Register) zverejneného Úradom pre reguláciu elektronických komunikácií a poštových služieb aktuálne aktívne pôsobí na Slovensku 23 poštových podnikov z 31 uverejnených, ktorým vypršala platnost' poštovej licencie, majú pozastavenú činnost', sú v likvidácií alebo boli zrušené. [12]

Následne boli vyhl'adávané informácie na webových stránkach aktívnych poštových operátorov z uvedeného Registra. ohl'adom doručovania ekologickým spôsobom $\mathrm{v}$ týchto spoločnostiach ako je možné vidiet' v tabul'ke č. 1 .

Tabul'ka 1 Poskytovanie zeleného doručovania poštovými operátormi s aktívnou činnost'ou v rozsahu Slovenskej republiky na základe Registra poštových služieb.

\begin{tabular}{|c|l|l|l|}
\hline PČ & \multicolumn{1}{|c|}{ Názov spoločnosti } & Poskytované služby & $\begin{array}{c}\text { Aktuálne využitie ekologického } \\
\text { doručovania na Slovensku }\end{array}$ \\
\hline 1 & KOLOS s.r.o. & Ostatné poštové služby & neuvedené \\
\hline 2 & $\begin{array}{l}\text { TNT Express Worldwide spol. s } \\
\text { r.o. }\end{array}$ & Ostatné poštové služby & neuvedené* \\
\hline 3 & $\begin{array}{l}\text { ReMax Courier Service, spol. s } \\
\text { r.o. od } 1.10 .2021 \text { ako Packeta }\end{array}$ & Ostatné poštové služby & neuvedené \\
\hline
\end{tabular}




\begin{tabular}{|c|c|c|c|}
\hline & Courier Service s.r.o. [13] & & \\
\hline 4 & INSPEKTA SLOVAKIA, a. s. & Ostatné poštové služby & neuvedené \\
\hline 5 & GO4, s.r.o. & Ostatné poštové služby & $\begin{array}{l}\text { plne elektrická dodávka eNV200, } \\
\text { e-TAXI [14] }\end{array}$ \\
\hline 6 & Cromwell a. s. & $\begin{array}{l}\text { Zamenitel'né služby } \\
\text { Ostatné poštové služby }\end{array}$ & neuvedené \\
\hline 7 & $\begin{array}{l}\text { Direct Parcel Distribution SK } \\
\text { s.r.o. }\end{array}$ & Ostatné poštové služby & eNV200 Maxi [15] \\
\hline 8 & Slovak Parcel Service s.r.o. & Ostatné poštové služby & neuvedené \\
\hline 9 & $\begin{array}{l}\text { DHL Express (Slovakia), spol. s } \\
\text { r. o. }\end{array}$ & Ostatné poštové služby & neuvedené* \\
\hline 10 & $\begin{array}{l}\text { IN TIME, s.r.o. od 1.10.2021 } \\
\text { ako Express One Slovakia s.r.o. } \\
{[16]}\end{array}$ & Ostatné poštové služby & neuvedené \\
\hline 11 & $\begin{array}{l}\text { DER KURIER Slovakia spol. s } \\
\text { r. o. }\end{array}$ & Ostatné poštové služby & neuvedené \\
\hline 12 & $\begin{array}{l}\text { GLS General Logistics Systems } \\
\text { Slovakia s.r.o. }\end{array}$ & Ostatné poštové služby & elektrické dodávky eSprinter [17] \\
\hline 13 & $\begin{array}{l}\text { Mediaprint - Kapa Pressegrosso, } \\
\text { a.s. }\end{array}$ & $\begin{array}{l}\text { Zamenitel'né služby } \\
\text { Ostatné poštové služby }\end{array}$ & neuvedené \\
\hline 14 & $\begin{array}{l}\text { Železničná spoločnost' } \\
\text { Slovensko, a.s. }\end{array}$ & $\begin{array}{l}\text { Zamenitel'né služby } \\
\text { Ostatné poštové služby }\end{array}$ & neuvedené* \\
\hline 15 & Slovenská pošta, a.s. & $\begin{array}{l}\text { Univerzálna služba } \\
\text { Úradné zásielky } \\
\text { Poštový platobný styk } \\
\text { Ostatné poštové služby }\end{array}$ & neuvedené \\
\hline 16 & $\begin{array}{l}\text { Skynet Worldwide Express, } \\
\text { s.r.o. }\end{array}$ & Ostatné poštové služby & neuvedené \\
\hline 17 & GOIZ, s. r. o. & Ostatné poštové služby & neuvedené \\
\hline 18 & Newton Tech, s.r.o. & Ostatné poštové služby & neuvedené \\
\hline 19 & $\begin{array}{l}\text { SLOVENSKÝ DORUČOVACÍ } \\
\text { SYSTÉM, s.r.o. }\end{array}$ & Ostatné poštové služby & neuvedené \\
\hline 20 & Tomáš Teniak - TENA OIL & Ostatné poštové služby & neuvedené \\
\hline 21 & Packeta Slovakia s. r. o. & Ostatné poštové služby & neuvedené \\
\hline 22 & Fusion trans s.r.o. & $\begin{array}{l}\text { Zamenitel'né služby } \\
\text { Ostatné poštové služby }\end{array}$ & neuvedené \\
\hline Spolu & - & - & 3 \\
\hline
\end{tabular}

\section{Zdroj: [12], vlastné spracovanie, informácie získané z webových stránok poštových podnikov}

Spoločnost' TNT spustila v roku 2015 v Holandsku doručovanie pomocou elektromobilov expresné doručovanie vo vybraných mestách. [18] Spoločnost' DHL v zahraničí doručuje prostredníctvom elektromobilov, ale zaviedla aj zbernú službu Eurapid pre nákladnú dopravu, na zníženie dopadu na životné prostredie. [19], [20] Spoločnost' GLS na Slovensku implementovala medzi vozidlá doručovacej flotily 21 elektromobilov. [17] Železničná spoločnost' Slovensko doručuje zásielky v rámci 17 železničných staníc na Slovensku. [21], [22], [23]

$\mathrm{Na}$ základe analýzy sme zistili, že len tri podniky z uvedených poštových podnikov implementovali do svojho logistického parku ekologické vozidlá, $\mathrm{z}$ toho až v dvoch prípadoch sa jednalo o elektrickú dodávku eNV200 a jeden typ eSprinter. Na stránkach zvyšných poštových podnikov sme nenarazili na zmienku o konkrétnom type vozidiel, ktorými doručujú zásielky, prípadne boli zmienky o týchto vozidlách uvedené, avšak ich zavedenie bolo spustené len v zahraničí. Tieto sú v tabul'ke označené s hviezdičkou. 


\section{Záver}

Vzhl'adom na snahu Európskej únie, ako aj jednotlivých členských štátov, je kl'účové aby jednotlivé osoby, či už fyzické alebo právnické znižovali ekologický dopad na životné prostredie. Jednou z možností je aj znižovanie emisií produkovaných dopravnými prostriedkami $v$ rámci distribučnej činnosti jednotlivých podnikov, najmä podnikov poskytujúcich logistické a poštové služby. Na Slovensku je však implementovanie ekologickejších typov vozidiel v poštových podnikoch zjavne na pomerne nízkej úrovni, ked'že z uvedených 22 podnikov tieto vozidlá využívajú len 3 podniky, čo predstavuje 13,6\%.

Otázne je však, či tieto podniky považujú elektromobily za ekologické, vzhl'adom na odpad, ktorý predstavujú batérie, ktoré tieto vozidlá poháňajú, ked’že kontroverzne, tieto nemožno považovat' za ekologické.

\section{Literatúra}

[1] J. Novák, O. Sadílek, Z. Novák, "Hybridní pohon posunovací lokomotivy,” In: Elektro, Vol. 29, no. 6, p. 4, 2019.

[2] J. Procházka, "Prototyp čínskeho vlaku maglev dosiahne rýchlost' $620 \mathrm{~km} / \mathrm{h}$ TECHBOX.sk," E-mobilita, TECHbox, 2021. [Cit. 8.10.2021]. Dostupné online na: https://techbox.dennikn.sk/prototyp-cinskeho-vlaku-maglev-dosiahne-rychlost-620$\mathrm{km}-\mathrm{h} /$.

[3] "Hybrid info: Všetko čo potrebujete vediet' o hybridných automobiloch," MôjElektromobil, 2018. [Cit. 8.10.2021]. Dostupné online na: https://www.mojelektromobil.sk/hybrid/.

[4] B. Mazanka, "Hybrid, plug-in hybrid, LPG a CNG. Na čo všetko sa jazdí | Dámska jazda | Dámska jazda | Auto.Rodinka.sk," 2021. [Cit. 8.10.2021]. Dostupné online na: https://auto.rodinka.sk/damska/jazda/hybrid-plug-in-hybrid-lpg-a-cng-na-co-vsetko-sajazdi/.

[5] "CNG motor / Nové Daily HI-MATIC Natural Power." [Cit. 8.10.2021]. Dostupné online na: https://www.iveco.com/slovakia/produkty/pages/plyn-motor-daily-naturalpower.aspx.

[6] V. Ilin and D. Simić, "Information and communication technologies shaping the inteligent logistics systems," In: Proceedings of First International Conference on Traffic and Transport Engineering - ICTTE Belgrade 2012, pp. 346-352, 2012. [Cit. 4.10.2021].

[7] M. Mitro, "Najlacnejšia jazda autom v SR. Ktorý z pohonov vyhrá? (test)," Elektromobilita, 2021. [Cit. 8.10.2021]. Dostupné online na: https://fontech.startitup.sk/najlacnejsie-jazdenie-autom-vyhra-benzin-diesel-plug-inhybrid-alebo-cng-zistili-sme/.

[8] T. Andrejčák, “Je vodík slepá ulička? Stále viac automobiliek si to myslí - Magazín Auto - Pravda," Pravda, 2021. [Cit. 8.10.2021]. Dostupné online na: https://auto.pravda.sk/magazin/clanok/581670-je-vodik-slepa-ulicka-stale-viacautomobiliek-si-to-mysli/.

[9] Zpráva o společenské odpovědnosti České pošty za rok 2020, Česká pošta, s.p. 2020. [Cit. 18.10.2021]. Dostupné online na: https://www.ceskaposta.cz/documents/10180/6784371/\%C4\%8CESK\%C3\%81_PO\%C 5\%A0TA_ZPR\%C3\%81VA_CSR_2020.pdf/c570501c-64c6-dd47-ea54-84c0a $\overline{6}$ a34de5

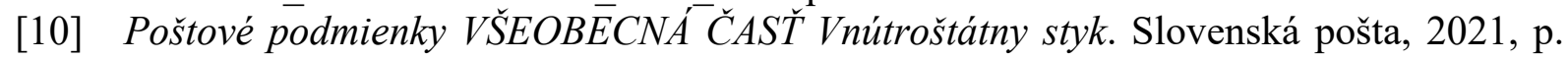
33. [Cit. 7.10.2021]. Dostupné online na: https://www.posta.sk/subory/36961/postovepodmienky-vseobecna-cast-vnutrostatny-styk.pdf.

[11] “CYKLOKURIÉR ŠVIHAJ ŠUHAJ." [Cit. 8.10.2021]. Dostupné online na: 
https://svihajsuhaj.sk/.

[12] Register poštových podnikov. Služieb, Úrad pre reguláciu elektronických komunikácií a poštových, 2021. [Cit. 7.10.2021]. Dostupné online na: https://www.teleoff.gov.sk/zoznam-podnikov/.

[13] "Zmena obchodného názvu ReMaxu na Packeta Courier Service," 2021. [Cit. 8.10.2021]. Dostupné online na: https://www.remax.sk/sk-sk/.

[14] "História - Kuriér GO4 | Expresné kuriérske služby," 2021. [Cit. 8.10.2021]. Dostupné online na: https://www.go4.sk/o-nas/historia/.

[15] "Ekologická a zodpovedná preprava tovaru | O DPD» DPD," 2021. [Cit. 8.10.2021]. Dostupné online na: https://www.dpd.com/sk/sk/udrzatelnost/.

[16] "IN TIME sa mení na EXPRESS ONE SLOVAKIA | intime.sk," 2021. [Cit. 8.10.2021]. Dostupné online na: http://www.expressone.sk/sk/kontakt/aktuality/intime-sa-meni-na-express-one-slovakia.html.

[17] “ThinkGreen | GLS Slovakia." [Cit. 8.10.2021]. Dostupné online na: https://glsgroup.eu/SK/sk/o-gls/skupina-gls/thinkgreen.

[18] "TNT introduces electric express delivery vehicles in Amsterdam and Rotterdam | TNT Slovakia," 2015. [Cit. 8.10.2021]. Dostupné online na: https://www.tnt.com/express/sk_sk/site/press/releases/tnt-introduces-electric-expressdelivery-vehicles-amsterdam-rotterdam.html.

[19] “Eurapid je odteraz ekologický: DHL Freight vytvára prvú plne udržatel’nú prémiovú zbernú službu LTL | DHL | Slovensko,” Bonn, 2020. [Cit. 8.10.2021]. Dostupné online na: $\quad$ https://www.dhl.com/sk-sk/home/tlac/archiv-tlace/2020/eurapid-je-odterazekologicky-dhl-freight-vytvara-prvu-plne-udrzate-nu-premiovu-zbernu-sluzbu-ltl.html.

[20] "Green last mile \& line haul," 2021. [Cit. 8.10.2021]. Dostupné online na: https://www.dpdhl.com/en/sustainability/environment/green-last-mile-line-haul.html.

[21] as Etický kódex Železničnej spoločnosti Slovensko, “Železničná spoločnost'," 2013. [Cit. 8.10.2021]. Dostupné online na: https://www.zssk.sk/uploads/tx_main/2013/04/19/eticky_kodex_2013.pdf.

[22] “Kuriér - Železničná spoločnost' Slovensko a.s.” [Cit. 8.10.2021]. Dostupné online na: https://www.zssk.sk/sluzby/sluzby-na-stanici/kurier/.

[23] “Vízia - Železničná spoločnost' Slovensko a.s.” [Cit. 8.10.2021]. Dostupné online na: https://www.zssk.sk/o-spolocnosti/vizia/.

\section{Grantová podpora}

The Paper is published with the support of project VEGA 1/0518/19. This research has been further supported by the University of Zilina in the scope of Institutional research $1 / \mathrm{KS} / 2020$, by Project K-21-015-00 and Project CIS by Ministry of Educations SR. 